\title{
MECHANISM OF PULMONARY VASOCONSTRICTION AFTER INJECTION OF 5-HYDROXYTRYPTAMINE IN THE DOG
}

\author{
BY \\ E. VITOLO, M. OBBIASSI, G. P. ZOCCHE, AND G. C. SCOTTI \\ Istituto di Patologia Medica dell'Università (Dir. Prof. G. Melli), Milan, Italy \\ Received September 13, 1961
}

The hypertensive action of 5-hydroxytryptamine (5-HT) on the pulmonary circulation of the dog has been studied by a number of workers during the past few years. They all agree that pulmonary hypertension of this origin is due to arteriolar vasoconstriction (McCanon and Horvath, 1954; Borst et al., 1956; Vitolo et al., 1957; Bracco and Curti, 1958; Carlier et al., 1958; GomezFerrer, 1958; Kabins et al., 1959; Shepherd et al., 1959; Fowler, 1960). In fact, according to some authors, 5-HT is the most powerful pulmonary vasoconstrictor there is (Ginzel and Kottegoda, 1953; Borst et al., 1957; Attinger, 1957, 1959; Gilbert et al., 1957, 1958; Rose and Lazaro, 1958).

Very little is known about the mechanism whereby pulmonary vasoconstriction is produced. Rose (1957), using a system of partial extracorporeal circulation, injected 5-HT in such a way that it came into contact only with the pulmonary vascular bed; the hypertension thus elicited was attributed to a direct action on the pulmonary vessels. Rudolph and Paul (1957) similarly came to the conclusion that 5-HT acts directly on the pulmonary arteriolar tone. Finally, bilateral cervical vagotomy, alone (Rose and Lazaro, 1958) or combined with section of the spinal cord (Nahas, 1958; Nahas and McDonald, 1959), has been shown to be incapable of modifying the pulmonary pressor response to 5-HT in the dog. However, as far as we know, the classical methods of studying circulatory physiopathology (adrenalectomy, section of the spinal cord, interaction with metabolites, sympatholytics and adrenolytics, etc.) have not so far been applied sufficiently for conclusive results to be obtained. Furthermore these experiments have largely been aimed at discovering the action of 5-HT on the peripheral circulation in various animal species, but we know that the effects of this substance vary to a considerable degree according to the species of animal, the dosage, the means, and the route of administration. These considerations prevent us from accepting the results so far obtained from experiments on other species of animals or in other regions of the canine circulation as valid for the action of 5-HT on the pulmonary circulation of the dog.

The lack of studies on the subject, the powerful action of 5-HT on the pulmonary circulation, and the fact that it is the only substance so far known which will act on the pulmonary circulation in a dose insufficient to influence the systemic circulation (Rose, 1957) all led us to continue our studies of the mechanism by which 5-HT produces pulmonary vasoconstriction in the dog.

The object of the present study was to discover whether 5-HT produces pulmonary vasoconstriction by increasing the nervous tone through stimulation of the sympathetic nerves or by releasing vaso-active substances originating in the adrenal medulla. To study the first possibility, the changes in pulmonary hæmodynamics following injection of 5-HT in the dog in basal conditions were compared with those following ganglionic block of sympathetic impulses with hexamethonium. Then. to exclude the possibility of interference by humoral factors, bilateral adrenalectomy was performed in a second group of dogs. This procedure is more difficult than the pharmacological method bu1 
more reliable in its effects since the possibility of the presence of other zones of chromaffin tissue acting as a source of sympathomimetic amines is negligible in the normal animal.

\section{METHOD}

The experiments were carried out on 22 medium-sized adult dogs of both sexes under chloralose anæsthesia. Through cardiac catheters connected with Sanborn electromanometers, mean pressures in the pulmonary artery and veins were recorded continuously and simultaneously on a TwinViso Sanborn machine. The pressure in the femoral artery was also measured with a mercury manometer. As in our earlier experiments (Vitolo et al., 1957), we used the lyophilized bisulphate of 5-hydroxytryptamine and of lyophilized creatinine, dissolved in normal saline before use. This was injected rapidly into the femoral vein in a dosage of $5 \mathrm{mg}$. $/ \mathrm{kg}$. of body weight.

In a first group of $10 \mathrm{dogs}$, the injection was repeated after intravenous injection of hexamethonium bitartrate in a dosage of $5 \mathrm{mg} . / \mathrm{kg}$. of hexamethonium ion. Ganglionic block was demonstrated by the disappearance of the carotid sinus reflex, the absence of which was confirmed before and after the subsequent injection of 5-HT.

In a second group of 12 dogs a second injection of 5-HT was given after bilateral adrenalectomy by the translumbar approach.

The effect on each vascular region studied and on the pulmonary arteriovenous gradient was examined after injection of 5-HT (1) into the intact animal, (2) under the influence of ganglioplegics and (3) after adrenalectomy, and also in the intact animal (4) after adrenalectomy and (5) under the influence of ganglioplegics. The results of each of these experiments were analysed statistically by calculating the arithmetic mean $(\bar{x})$ and the scatter expressed as standard deviation (s). These means were compared with each other by analysis of the variance, calling, as is usual, "non signifcant" the differences that could be due to chance with a probability greater than 5 per cent $(p>0.05)$, "significant" where the probability is less than 5 per cent $(p<0.05)$ and "highly significant" where the probability is less than 1 per cent $(\mathrm{p}<0 \cdot 01)$.

\section{RESULTS}

The pressures observed during the individual experiments are shown in Table I. Action of 5-HT in the Intact Animal (Table II)

In all 22 cases in which the injection of 5-HT was carried out in the intact animal, a "highly significant" increase in pulmonary arterial pressure was observed (mean 16.68 $\pm 9 \cdot 26 \mathrm{~mm}$. $\mathrm{Hg}$ ). In the pulmonary vein too, a highly significant rise in pressure (mean $10.90 \pm 7.41 \mathrm{~mm}$. Hg) was found in all cases but one. The arteriovenous gradient was increased in 20 cases, diminished in 1, and unchanged in 1 . The mean values showed a change in this gradient from $10 \cdot 18 \pm 6 \cdot 10 \mathrm{~mm}$. $\mathrm{Hg}$ before injection to $19.54 \pm 11.06 \mathrm{~mm}$. $\mathrm{Hg}$ after injection of 5-HT, with a highly significant mean increase of $9.36 \pm 7.72 \mathrm{~mm}$. $\mathrm{Hg}$. In the femoral artery there was an increase in systolic pressure in 20 cases, a reduction in 1, and no change in 1, with a highly significant mean increase of $60.90 \pm 42.94 \mathrm{~mm}$. Hg.

\section{Action of Hexamethonium (Table III)}

In the 10 cases in which it was studied, the administration of hexamethonium produced a fall in the pressure in the pulmonary artery in 8 , and no change in 2 cases. There was thus a mean fall in pressure of $5 \cdot 10 \pm 5.02 \mathrm{~mm}$. $\mathrm{Hg}$, which is not statistically significant. In the pulmonary vein, pressure was observed to fall in 8 cases, increase in 1, and remain unchanged in 1. Altogether there was a mean fall in pressure of $3 \cdot 40 \pm 4 \cdot 11 \mathrm{~mm}$. $\mathrm{Hg}$, which is statistically significant. The pulmonary arteriovenous gradient diminished in 5 cases, increased in 4, and remained unchanged in 1 case. Thus the gradient diminished by $1.70 \pm 6.00 \mathrm{~mm}$. $\mathrm{Hg}$, which is not significant. In the femoral artery, the injection of hexamethonium produced a fall in pressure in all cases but one in which it was unchanged, the mean decrease being $46 \cdot 50 \pm 25.50 \mathrm{~mm}$. $\mathrm{Hg}$, which is highly significant. 
TABLE I

Mean Pressures (Mm. Hg) OBSERVEd duRING the Individual EXPeriments

\begin{tabular}{|c|c|c|c|c|c|c|c|c|c|c|c|c|c|c|c|c|}
\hline \multirow{3}{*}{$\begin{array}{l}\text { Case } \\
\text { No. }\end{array}$} & \multicolumn{4}{|c|}{ Pulmonary artery } & \multicolumn{4}{|c|}{ Pulmonary vein } & \multicolumn{4}{|c|}{ Pulmon. A/V grad. } & \multicolumn{4}{|c|}{ Femoral artery } \\
\hline & \multicolumn{2}{|c|}{$\begin{array}{c}\text { Intact } \\
\text { animal }\end{array}$} & \multicolumn{2}{|c|}{$\begin{array}{c}\text { After } \\
\text { hexameth. }\end{array}$} & \multicolumn{2}{|c|}{$\begin{array}{l}\text { Intact } \\
\text { animal }\end{array}$} & \multicolumn{2}{|c|}{$\begin{array}{c}\text { After } \\
\text { hexameth. }\end{array}$} & \multicolumn{2}{|c|}{$\begin{array}{c}\text { Intact } \\
\text { animal }\end{array}$} & \multicolumn{2}{|c|}{$\begin{array}{c}\text { After } \\
\text { hexameth. }\end{array}$} & \multicolumn{2}{|c|}{$\begin{array}{c}\text { Intact } \\
\text { animal }\end{array}$} & \multicolumn{2}{|c|}{$\begin{array}{c}\text { After } \\
\text { hexameth. }\end{array}$} \\
\hline & Bas. & $\begin{array}{l}\text { After } \\
5-\mathrm{HT}\end{array}$ & Bas. & $\begin{array}{l}\text { After } \\
\text { 5-HT }\end{array}$ & Bas. & $\begin{array}{l}\text { After } \\
\text { 5-HT }\end{array}$ & Bas. & $\begin{array}{l}\text { After } \\
\text { 5-HT }\end{array}$ & Bas. & $\begin{array}{l}\text { After } \\
5-\mathrm{HT}\end{array}$ & Bas. & $\begin{array}{l}\text { After } \\
5-\mathrm{HT}\end{array}$ & Bas. & $\begin{array}{l}\text { After } \\
5-\mathrm{HT}\end{array}$ & Bas. & $\begin{array}{l}\text { After } \\
\text { 5-HT }\end{array}$ \\
\hline $\begin{array}{r}1 \\
2 \\
3 \\
4 \\
5 \\
6 \\
7 \\
8 \\
9 \\
10 \\
\end{array}$ & $\begin{array}{r}8 \\
5 \\
20 \\
17 \\
28 \\
12 \\
17 \\
12 \\
6 \\
5 \\
\end{array}$ & $\begin{array}{l}20 \\
12 \\
30 \\
27 \\
68 \\
35 \\
44 \\
35 \\
35 \\
22 \\
\end{array}$ & $\begin{array}{r}2 \\
5 \\
10 \\
10 \\
12 \\
7 \\
15 \\
8 \\
5 \\
5\end{array}$ & $\begin{array}{l}15 \\
12 \\
28 \\
25 \\
32 \\
17 \\
54 \\
32 \\
32 \\
25\end{array}$ & $\begin{array}{r}5 \\
0 \\
1 \\
7 \\
7 \\
2 \\
-2 \\
7 \\
4 \\
2 \\
\end{array}$ & $\begin{array}{r}10 \\
5 \\
7 \\
17 \\
28 \\
10 \\
5 \\
32 \\
17 \\
18 \\
\end{array}$ & $\begin{array}{r}2 \\
0 \\
-1 \\
-5 \\
5 \\
0 \\
0 \\
0 \\
0 \\
-2 \\
\end{array}$ & $\begin{array}{r}12 \\
2 \\
2 \\
0 \\
5 \\
2 \\
0 \\
5 \\
12 \\
-10 \\
\end{array}$ & $\begin{array}{r}3 \\
5 \\
19 \\
10 \\
21 \\
10 \\
19 \\
5 \\
2 \\
3\end{array}$ & $\begin{array}{r}11 \\
10 \\
25 \\
13 \\
40 \\
25 \\
42 \\
-7 \\
23 \\
13\end{array}$ & $\begin{array}{r}0 \\
5 \\
11 \\
15 \\
7 \\
7 \\
15 \\
8 \\
5 \\
7\end{array}$ & $\begin{array}{l}10 \\
11 \\
26 \\
26 \\
28 \\
15 \\
54 \\
30 \\
24 \\
28\end{array}$ & $\begin{array}{r}60 \\
130 \\
140 \\
150 \\
150 \\
150 \\
150 \\
160 \\
100 \\
110\end{array}$ & $\begin{array}{l}100 \\
200 \\
240 \\
195 \\
220 \\
160 \\
250 \\
280 \\
200 \\
280\end{array}$ & $\begin{array}{r}40 \\
65 \\
90 \\
110 \\
150 \\
70 \\
125 \\
85 \\
50 \\
50\end{array}$ & $\begin{array}{r}140 \\
130 \\
220 \\
180 \\
195 \\
95 \\
250 \\
220 \\
150 \\
150\end{array}$ \\
\hline $\begin{array}{c}n=10 \\
(\text { Cases } \\
1-10) \\
\bar{x} \\
\mathrm{~s}\end{array}$ & $\begin{array}{r}13 \cdot 00 \\
7 \cdot 52 \\
\end{array}$ & $\begin{array}{l}32 \cdot 80 \\
15 \cdot 39 \\
\end{array}$ & $\begin{array}{l}7 \cdot 90 \\
3 \cdot 90\end{array}$ & $\begin{array}{l}27 \cdot 20 \\
11 \cdot 93\end{array}$ & $\begin{array}{l}3 \cdot 30 \\
3 \cdot 19\end{array}$ & $\begin{array}{r}14.90 \\
9.36\end{array}$ & $\begin{array}{r}-0 \cdot 10 \\
2 \cdot 55\end{array}$ & $\begin{array}{l}3 \cdot 00 \\
6 \cdot 32\end{array}$ & $\begin{array}{l}9 \cdot 70 \\
7 \cdot 40\end{array}$ & $\begin{array}{l}19 \cdot 50 \\
14 \cdot 71\end{array}$ & $\begin{array}{l}8 \cdot 00 \\
4 \cdot 69\end{array}$ & $\begin{array}{l}25 \cdot 20 \\
12 \cdot 50\end{array}$ & $\begin{array}{r}130 \cdot 00 \\
31 \cdot 26\end{array}$ & $\begin{array}{r}212 \cdot 50 \\
55 \cdot 13\end{array}$ & $\begin{array}{l}83 \cdot 50 \\
35 \cdot 82\end{array}$ & $\begin{array}{r}173 \cdot 00 \\
48 \cdot 25\end{array}$ \\
\hline & & & $\begin{array}{r}\text { Af } \\
\text { adren }\end{array}$ & $\begin{array}{l}\text { er } \\
\text { alect. }\end{array}$ & & & $\begin{array}{r}\text { A } \\
\text { adrer }\end{array}$ & ect. & & & $\begin{array}{r}\text { Af } \\
\text { adren }\end{array}$ & er & & & $\begin{array}{r}\text { Af } \\
\text { adren }\end{array}$ & $\begin{array}{l}\text { er } \\
\text { alect. }\end{array}$ \\
\hline & & & Bas. & $\begin{array}{c}\text { After } \\
\text { 5-HT }\end{array}$ & & & Bas. & $\begin{array}{l}\text { After } \\
\text { 5-HT }\end{array}$ & & & Bas. & $\begin{array}{l}\text { After } \\
\text { 5-HT }\end{array}$ & & & Bas. & $\begin{array}{l}\text { After } \\
\text { 5-HT }\end{array}$ \\
\hline $\begin{array}{l}11 \\
12 \\
13 \\
14 \\
15 \\
16 \\
17 \\
18 \\
19 \\
20 \\
21 \\
22\end{array}$ & $\begin{array}{r}15 \\
10 \\
15 \\
10 \\
12 \\
11 \\
14 \\
20 \\
5 \\
25 \\
10 \\
8\end{array}$ & $\begin{array}{l}40 \\
12 \\
30 \\
24 \\
28 \\
18 \\
22 \\
35 \\
17 \\
40 \\
40 \\
18\end{array}$ & $\begin{array}{r}5 \\
2 \\
2 \\
5 \\
12 \\
1 \\
6 \\
10 \\
0 \\
12 \\
6 \\
10 \\
\end{array}$ & $\begin{array}{r}12 \\
10 \\
17 \\
12 \\
22 \\
5 \\
16 \\
25 \\
10 \\
28 \\
20 \\
35 \\
\end{array}$ & $\begin{array}{r}10 \\
0 \\
7 \\
6 \\
2 \\
-4 \\
10 \\
7 \\
-10 \\
5 \\
-5 \\
0 \\
\end{array}$ & $\begin{array}{r}30 \\
2 \\
15 \\
19 \\
12 \\
1 \\
12 \\
7 \\
10 \\
12 \\
20 \\
12 \\
\end{array}$ & $\begin{array}{r}-10 \\
5 \\
2 \\
-11 \\
5 \\
-7 \\
2 \\
-5 \\
0 \\
0 \\
-10 \\
2 \\
\end{array}$ & $\begin{array}{r}-2 \\
6 \\
15 \\
-11 \\
0 \\
-7 \\
3 \\
-8 \\
7 \\
10 \\
3 \\
8 \\
\end{array}$ & $\begin{array}{r}5 \\
10 \\
8 \\
4 \\
10 \\
15 \\
4 \\
13 \\
15 \\
20 \\
15 \\
8\end{array}$ & $\begin{array}{l}17 \\
10 \\
18 \\
10 \\
20 \\
18 \\
15 \\
28 \\
27 \\
28 \\
32 \\
12\end{array}$ & $\begin{array}{r}15 \\
-3 \\
0 \\
16 \\
10 \\
8 \\
4 \\
15 \\
0 \\
12 \\
16 \\
8 \\
\end{array}$ & $\begin{array}{r}17 \\
8 \\
5 \\
23 \\
24 \\
13 \\
14 \\
32 \\
7 \\
28 \\
22 \\
33 \\
\end{array}$ & $\begin{array}{r}140 \\
60 \\
160 \\
155 \\
170 \\
90 \\
160 \\
160 \\
90 \\
180 \\
140 \\
140 \\
\end{array}$ & $\begin{array}{r}200 \\
90 \\
160 \\
260 \\
200 \\
140 \\
150 \\
180 \\
140 \\
240 \\
220 \\
180 \\
\end{array}$ & $\begin{array}{r}40 \\
65 \\
60 \\
50 \\
150 \\
20 \\
10 \\
130 \\
100 \\
160 \\
140 \\
140\end{array}$ & $\begin{array}{r}70 \\
90 \\
90 \\
100 \\
220 \\
35 \\
20 \\
160 \\
110 \\
240 \\
220 \\
220\end{array}$ \\
\hline $\begin{array}{c}\mathrm{n}=12 \\
\text { (Cases } \\
11-22) \\
\bar{x} \\
\mathrm{~s}\end{array}$ & $\begin{array}{r}12 \cdot 91 \\
5 \cdot 41\end{array}$ & $\begin{array}{l}27 \cdot 00 \\
10 \cdot 00\end{array}$ & $\begin{array}{l}5 \cdot 91 \\
4 \cdot 25\end{array}$ & $\begin{array}{r}17 \cdot 66 \\
8 \cdot 68\end{array}$ & $\begin{array}{l}2 \cdot 33 \\
6 \cdot 31\end{array}$ & $\begin{array}{r}12.66 \\
7.92\end{array}$ & $\begin{array}{r}-2 \cdot 25 \\
6 \cdot 00\end{array}$ & $\begin{array}{l}2 \cdot 00 \\
7 \cdot 87\end{array}$ & $\begin{array}{r}10 \cdot 58 \\
5.08\end{array}$ & $\begin{array}{r}19 \cdot 58 \\
7 \cdot 53\end{array}$ & $\begin{array}{l}8 \cdot 41 \\
6 \cdot 80\end{array}$ & $\begin{array}{r}18 \cdot 83 \\
9 \cdot 63 \\
\end{array}$ & $\begin{array}{r}137 \cdot 08 \\
37 \cdot 20\end{array}$ & $\begin{array}{r}180.00 \\
47.67\end{array}$ & $\begin{array}{l}88 \cdot 75 \\
53 \cdot 17\end{array}$ & $\begin{array}{r}131 \cdot 25 \\
77 \cdot 75\end{array}$ \\
\hline
\end{tabular}

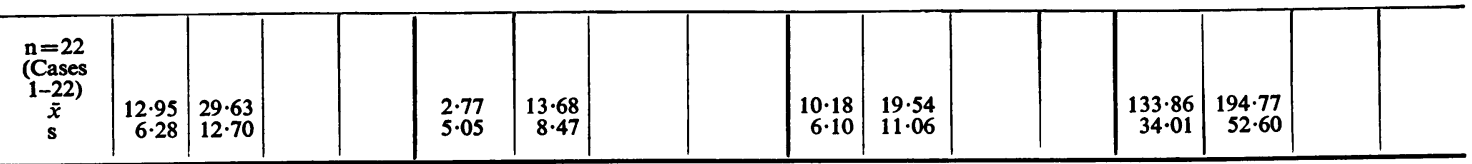

$\mathrm{n}=$ sample size (number of observations).

$\bar{x}=$ sample arithmetic mean.

$\mathrm{s}=$ sample standard deviation.

TABLE II

Pressure Changes due to 5-HT (In A total of 22 dogs)

\begin{tabular}{c|r|r|r|r}
\hline $\mathrm{n}=22$ & $\begin{array}{c}\text { Pulmonary } \\
\text { artery }\end{array}$ & $\begin{array}{c}\text { Pulmonary } \\
\text { vein }\end{array}$ & $\begin{array}{c}\text { Art/ven } \\
\text { gradient }\end{array}$ & $\begin{array}{c}\text { Femoral } \\
\text { artery }\end{array}$ \\
\cline { 2 - 4 } & +16.68 & +10.90 & +9.36 & +60.90 \\
$\bar{x}$ & 9.26 & 7.41 & 7.72 & 42.94 \\
$\mathrm{~F}$ & 30.23 & 26.91 & 37.64 & 20.79 \\
$\mathrm{p}$ & $<0.01$ & $<0.01$ & $<0.01$ & $<0.01$ \\
\hline
\end{tabular}

$\mathrm{n}=$ sample size (number of observations)

$\bar{x}=$ sample arithmetic mean

$\mathrm{s}=$ standard deviation

$\mathbf{F}=$ variance ratio

$\mathrm{p}=$ probability $(>0.05=$ non significant $;<0.05=$ significant $;<0.01=$ highly significant $)$. 
TABLE III

Pressure Changes due to Hexamethonium in the Intact Animal

\begin{tabular}{c|r|r|r|r}
\hline $\mathrm{n}=10$ & $\begin{array}{c}\text { Pulmonary } \\
\text { artery }\end{array}$ & $\begin{array}{c}\text { Pulmonary } \\
\text { vein }\end{array}$ & $\begin{array}{c}\text { Art/ven } \\
\text { gradient }\end{array}$ & $\begin{array}{c}\text { Femoral } \\
\text { artery }\end{array}$ \\
\hline $\bar{x}$ & -5.10 & -3.40 & -1.70 & -46.50 \\
$\mathrm{~s}$ & 5.02 & 4.11 & 6.00 & 25.50 \\
$\mathrm{~F}$ & 3.61 & 6.89 & 0.37 & 9.64 \\
$\mathrm{p}$ & $>0.05$ & $<0.05$ & $>0.05$ & $<0.01$ \\
\hline
\end{tabular}

(Symbols: see Table II).

TABLE IV

Pressure Changes due to Adrenalectomy in the Intact Animal

\begin{tabular}{c|c|c|c|c}
\hline $\mathrm{n}=12$ & $\begin{array}{c}\text { Pulmonary } \\
\text { artery }\end{array}$ & $\begin{array}{c}\text { Pulmonary } \\
\text { vein }\end{array}$ & $\begin{array}{c}\text { Art/ven } \\
\text { gradient }\end{array}$ & $\begin{array}{c}\text { Femoral } \\
\text { artery }\end{array}$ \\
\cline { 2 - 4 } & -7.00 & -4.58 & $-2 \cdot 16$ & -48.33 \\
$\mathrm{~s}$ & 4.74 & 8.87 & $8 \cdot 33$ & $\mathbf{5 4 . 1 1}$ \\
$\mathrm{F}$ & 12.39 & 3.32 & 0.78 & 6.65 \\
$\mathrm{p}$ & $<0.01$ & $>0.05$ & $>0.05$ & $<0.05$ \\
\hline
\end{tabular}

(Symbols: see Table II).

\section{Effect of Adrenalectomy (Table IV)}

In the 12 cases in which bilateral adrenalectomy was carried out, the pressure in the pulmonary artery fell in 10, was increased in 1, and remained unchanged in 1: there was a highly significant mean decrease of $7.00 \pm 4.74 \mathrm{~mm}$. Hg. In the pulmonary vein, the pressure fell in 8 cases and rose in 4: the mean decrease was $4.58 \pm 8.87 \mathrm{~mm}$. $\mathrm{Hg}$, which is statistically not significant. The pulmonary arteriovenous gradient diminished in 5 cases, increased in 4, and was unchanged in 3: there was a mean diminution of $2 \cdot 16 \pm 8.33 \mathrm{~mm}$. $\mathrm{Hg}$, which is statistically not significant. The pressure in the femoral artery fell in 8 cases, rose in 2, and remained unchanged in 2: the mean fall in pressure, $48 \cdot 33 \pm 54 \cdot 11 \mathrm{~mm}$. $\mathrm{Hg}$, is statistically significant.

\section{TABL̈E V}

Pressure Changes due to 5-HT after Ganglionic Block

\begin{tabular}{|c|c|c|c|c|c|c|c|c|c|c|c|c|}
\hline \multirow[t]{2}{*}{$\mathrm{n}=10$} & \multicolumn{3}{|c|}{ Pulmonary artery } & \multicolumn{3}{|c|}{ Pulmonary vein } & \multicolumn{3}{|c|}{ Art/ven gradient } & \multicolumn{3}{|c|}{ Femoral artery } \\
\hline & $\mathbf{a}$ & b & c & $\mathbf{a}$ & b & c & $\mathbf{a}$ & b & c & $\mathbf{a}$ & b & c \\
\hline $\begin{array}{l}\bar{x} \\
\mathbf{s} \\
\mathbf{F} \\
\mathbf{p}\end{array}$ & $\begin{array}{r}+19.80 \\
10.48 \\
13.34 \\
<0.01\end{array}$ & $\begin{array}{r}+19.30 \\
9.23 \\
23.63 \\
<0.01\end{array}$ & $\begin{array}{r}-0.50 \\
9.51 \\
0.01 \\
>0.05\end{array}$ & $\begin{array}{r}+11.60 \\
7.02 \\
13.74 \\
<0.01\end{array}$ & $\begin{array}{r}+3.10 \\
5.56 \\
2.06 \\
>0.05\end{array}$ & $\begin{array}{r}-8.50 \\
9.70 \\
8.99 \\
<0.01\end{array}$ & $\begin{array}{r}+9.80 \\
10.40 \\
3.53 \\
<0.05\end{array}$ & $\begin{array}{r}+17.20 \\
9.63 \\
16.64 \\
<0.01\end{array}$ & $\begin{array}{r}+7.40 \\
11.50 \\
2.72 \\
<0.05\end{array}$ & $\begin{array}{r}+82.50 \\
45.65 \\
16.93 \\
<0.01\end{array}$ & $\begin{array}{r}+89.50 \\
37.15 \\
22.16 \\
<0.01\end{array}$ & $\begin{array}{c}+7.00 \\
35.36 \\
0.14 \\
>0.05\end{array}$ \\
\hline
\end{tabular}

(a) Pressure changes due to 5-HT in the intact animal (cases 1-10).

(b) Pressure changes due to 5-HT in the animal after ganglionic block.

(c) Difference between the pressure changes in $(a)$ and $(b)$.

(Symbols: see Table II).

\section{Effect of Ganglionic Block on the Action of 5-HT (Table V, Fig. 1)}

In each of the animals in which 5-HT was injected after ganglionic block, there was a rise in pressure in the pulmonary artery which, with a mean of $19 \cdot 30 \pm 9 \cdot 23 \mathrm{~mm}$. $\mathrm{Hg}$, is highly significant. 
The difference between the change in pressure produced by 5-HT in basal conditions and after ganglionic block $(-0.50 \pm 9.51 \mathrm{~mm}$. $\mathrm{Hg})$ is not statistically significant. Injection of 5-HT after ganglion block provoked a rise in pressure in the pulmonary vein in 7 cases, a fall in 1 , and no change in 2 , the mean increase being $3 \cdot 10 \pm 5.56 \mathrm{~mm}$. $\mathrm{Hg}$, which is not statistically significant. This increase was much less than that obtained in the same animals in basal conditions

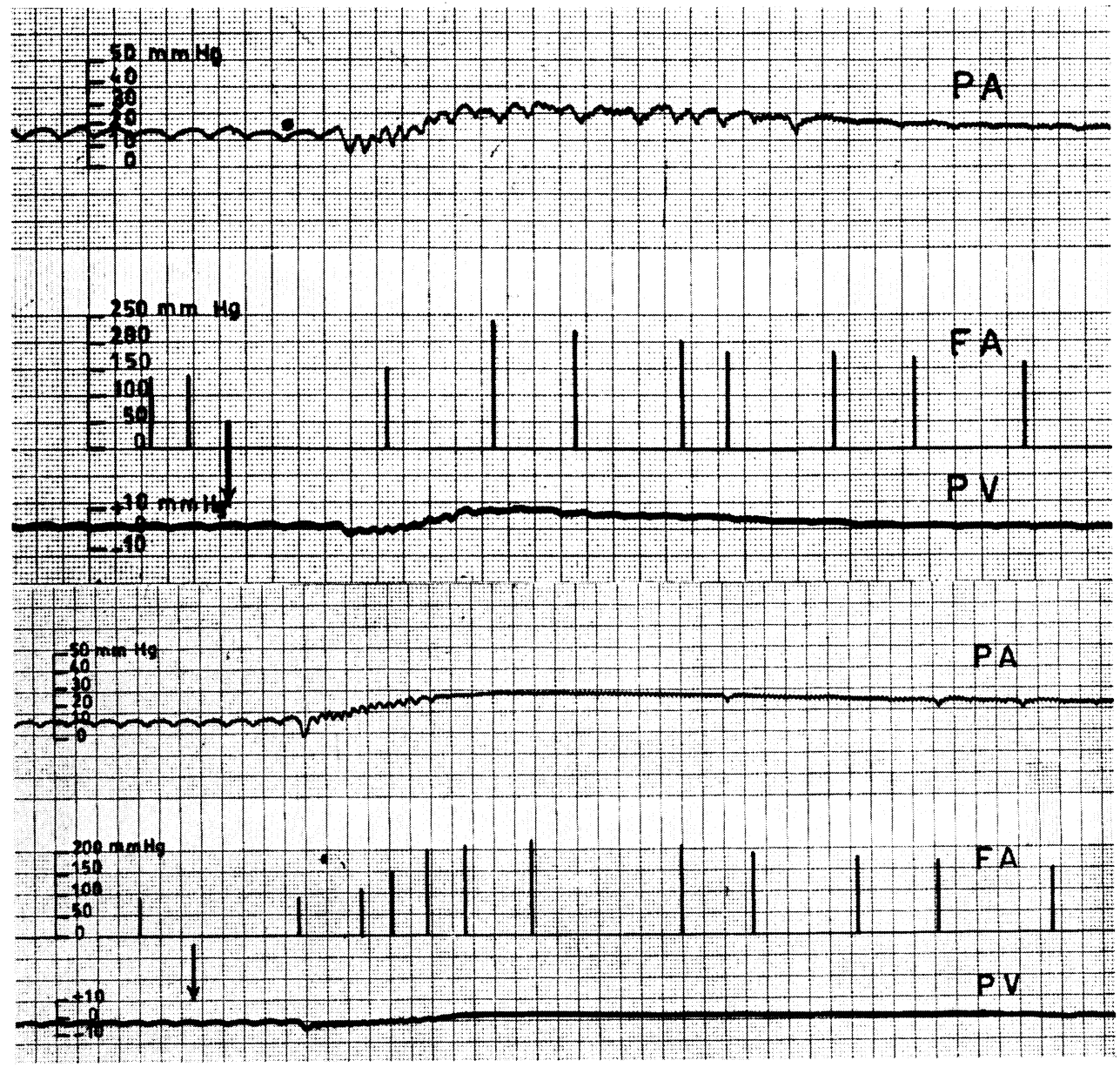

FIG. 1.-Injection of 5-HT (vertical arrow) in the intact animal (above) and after ganglionic block (below). One big square on the paper $=2$ sec. PA $=$ Pulmonary artery $; \quad$ FA $=$ Femoral artery $; \quad$ PV $=$ Pulmonary vein.

$(-8 \cdot 50 \pm 9 \cdot 70 \mathrm{~mm}$. $\mathrm{Hg})$. The pulmonary arteriovenous gradient increased in all cases: mean $17 \cdot 20 \pm 9.63 \mathrm{~mm}$. Hg which is highly significant. This increase does not differ statistically from that recorded in the same animals when 5 -HT was injected before hexamethonium $(+7 \cdot 40 \pm 11 \cdot 50 \mathrm{~mm}$. $\mathrm{Hg}$ ). The pressure in the femoral artery increased in all cases, the mean increase being $89 \cdot 50 \pm$ $37.15 \mathrm{~mm}$. $\mathrm{Hg}$, which is highly significant. This increase was not different statistically from that observed in the same animals when $5-\mathrm{HT}$ was injected before hexamethonium $(+7 \cdot 00 \pm 35 \cdot 36 \mathrm{~mm}$. $\mathrm{Hg})$. 
TABLE VI

Pressure Changes due to 5-HT after Adrenalectomy

\begin{tabular}{|c|c|c|c|c|c|c|c|c|c|c|c|c|}
\hline \multirow[t]{2}{*}{$n=12$} & \multicolumn{3}{|c|}{ Pulmonary artery } & \multicolumn{3}{|c|}{ Pulmonary vein } & \multicolumn{3}{|c|}{ Art/ven gradient } & \multicolumn{3}{|c|}{ Femoral artery } \\
\hline & $\mathbf{a}$ & b & c & $\mathbf{a}$ & b & c & $\mathbf{a}$ & b & c & a & b & c \\
\hline $\begin{array}{l}\bar{x} \\
\text { s } \\
\mathbf{F} \\
\mathrm{p}\end{array}$ & $\begin{array}{r}+14.09 \\
7.58 \\
18.37 \\
<0.01\end{array}$ & $\begin{array}{r}+11.75 \\
5.62 \\
17.70 \\
<0.01\end{array}$ & $\begin{array}{r}-2.34 \\
8.93 \\
0.73 \\
>0.05\end{array}$ & $\begin{array}{r}+10.33 \\
7.99 \\
12.48 \\
<0.01\end{array}$ & $\begin{array}{r}+4.25 \\
6.07 \\
2.21 \\
>0.05\end{array}$ & $\begin{array}{r}-6.08 \\
6.82 \\
5.54 \\
<0.05\end{array}$ & $\begin{array}{r}+9.00 \\
5.00 \\
11.75 \\
<0.01\end{array}$ & $\begin{array}{r}+10.42 \\
6.51 \\
9.35 \\
<0.01\end{array}$ & $\begin{array}{r}+1.42 \\
8.79 \\
0.35 \\
>0.05\end{array}$ & $\begin{array}{r}+42.92 \\
32.22 \\
6.04 \\
<0.05\end{array}$ & $\begin{array}{r}+42.50 \\
28.08 \\
2.44 \\
>0.05\end{array}$ & $\begin{array}{r}-0.42 \\
32.71 \\
0.00 \\
>0.05\end{array}$ \\
\hline
\end{tabular}

(a) Pressure changes due to 5-HT in the intact animal (Case 11-22).

(b) Pressure changes due to 5-HT in the adrenalectomized animal.

(c) Difference between the pressure changes in $(a)$ and $(b)$.

(Symbols: see Table II.)

Influence of Adrenalectomy on the Action of 5-HT (Table VI, Fig. 2)

After bilateral adrenalectomy, the injection of 5-HT produced in all cases a highly significant rise in pressure in the pulmonary artery (mean $11.75 \pm 5.62 \mathrm{~mm}$. $\mathrm{Hg}$ ). The difference between these

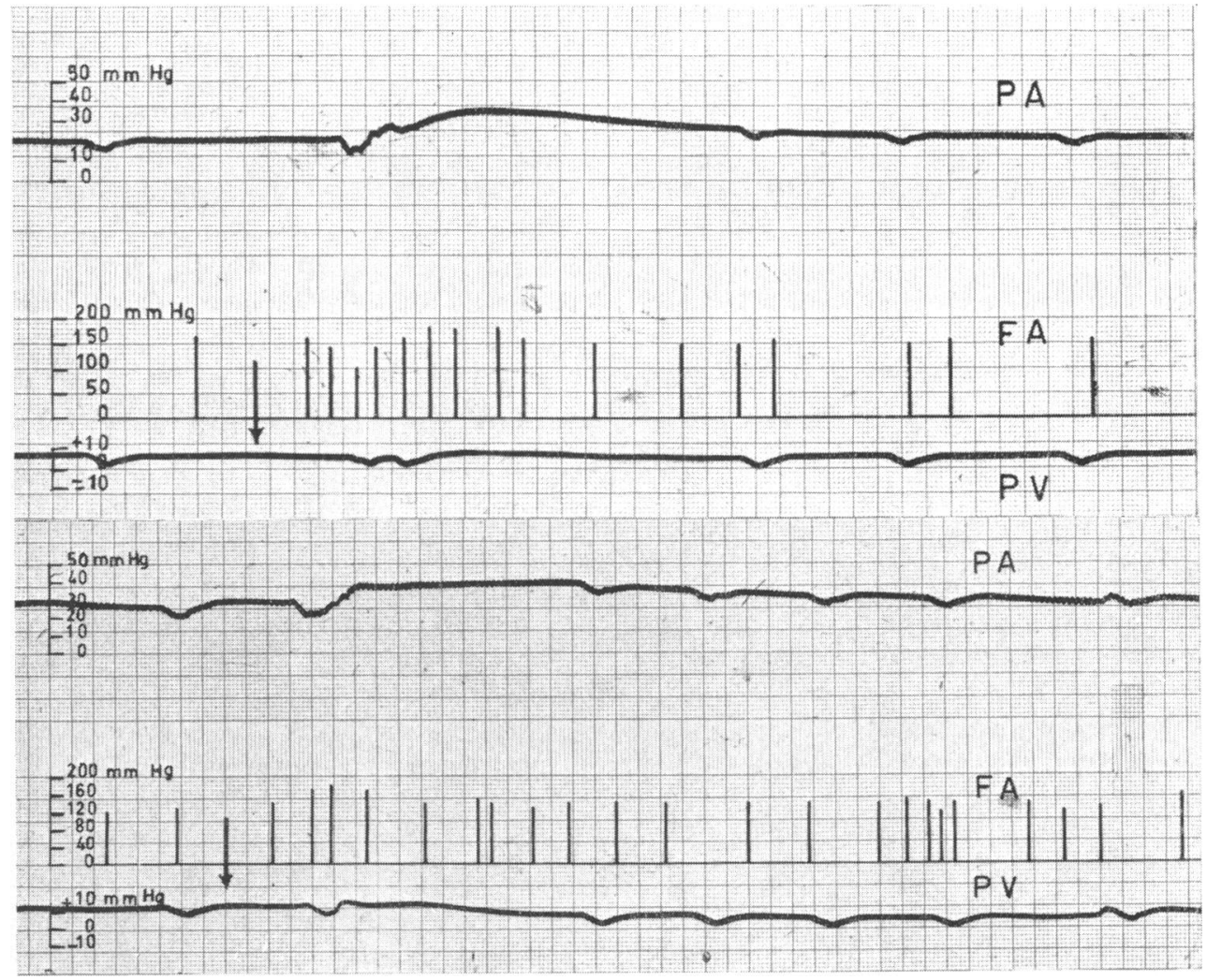

FIG. 2.- Injection of 5-HT (vertical arrow) in the intact animal (above) and after bilateral adrenalectomy (below).

One big square on the paper $=2 \mathrm{sec}$.

PA = Pulmonary artery $\quad$ FA $=$ Femoral artery $\quad \quad$ PV $=$ Pulmonary vein. 
values and those recorded in the intact animal $(-2.34 \pm 8.93 \mathrm{~mm} . \mathrm{Hg})$ is not statistically significant. The pressure in the pulmonary vein increased in 8 cases, decreased in 2 , and remained unchanged in 2 , with a mean increase of $4.25 \pm 6.07 \mathrm{~mm}$. $\mathrm{Hg}$, which is not statistically significant. This increase is significantly smaller than that recorded in the same animals in basal conditions $(-6.08 \pm 6.82$ $\mathrm{mm}$. $\mathrm{Hg}$ ). The pulmonary arteriovenous gradient showed a highly significant increase in all cases (mean $10.42 \pm 6.51 \mathrm{~mm}$. $\mathrm{Hg}$ ). The mean difference between the increase observed in basal conditions and that after adrenalectomy $(+1.42 \pm 8.79 \mathrm{~mm} . \mathrm{Hg})$ was not statistically significant. In the femoral artery also, there was an increase in pressure in all cases (mean $42 \cdot 50 \pm 28.08 \mathrm{~mm}$. $\mathrm{Hg}$ ), which however is not statistically significant. The difference between this and the increase observed after injection of 5-HT in basal conditions was not statistically significant $(-0.42 \pm$ $32.71 \mathrm{~mm}$. $\mathrm{Hg})$.

\section{Discussion}

The results obtained after injection of 5-HT into animals in basal conditions confirm that this substance produces an increase in pressure in the femoral and pulmonary arteries. The pressure in the pulmonary vein also shows a highly significant increase although smaller than that in the pulmonary artery. It can thus be confirmed that the pulmonary arteriovenous gradient determined in this way also increases highly significantly indicating a rise in pulmonary vascular resistance (Vitolo et al., 1957; Borst et al., 1957; Rudolph and Paul, 1957; Gilbert et al., 1957, 1958; Carlier et al., 1958; Nahas, 1958; Kabins et al., 1959; Nahas and MacDonald, 1959; Shepherd et al., 1959).

Pressure responses to 5-HT after administration of hexamethonium show that ganglionic block does not alter the systemic hypertensive response to 5-HT. Our results agree only in part with those of Page (1952) and Schneider and Yonkman (1954). These authors found that administration of ganglionic blockers (not hexamethonium) not only does not abolish or diminish the systemic hypertensive response to 5-HT but actually increases it.

Analysis of the hæmodynamic changes in the pulmonary circulation shows that the pulmonary hypertension is in no way affected by ganglionic block and thus the increased arteriovenous gradient remains similarly unchanged. This behaviour is significant enough for us to conclude that in the anæsthetized dog the abolition of vasomotor tone does not prevent hypertensive vasoconstrictor action on the pulmonary circulation. This action cannot therefore be mediated by a neurogenic mechanism.

The behaviour of the pressure in the pulmonary vein was quite different. Following ganglionic block, it rose significantly less than in basal conditions. It is not known which factor causes pulmonary venous hypertension following 5-HT-increased vasomotor tone, the retrograde effect of insufficient emptying of the left ventricle, increased flow through the pulmonary arteriovenous anastomoses, or other factors (Gilbert et al., 1957, 1958; Kabins et al., 1959). Nor is it known what is the real effect of hexamethonium on such phenomena (Yu et al., 1958). The methods used in our experiments do not permit us to go more deeply into this problem.

Adrenalectomy did not alter the systemic arterial hypertension produced by 5-HT. This result agrees with those of Page and McCubbin (1953), Schneider et al. (1954) and Thieblot et al. (1957). Similarly the pulmonary arterial pressure and the pulmonary arteriovenous gradient were not significantly modified. The possibility is thus excluded that the pulmonary arteriolar vasoconstriction induced by 5-HT in the dog is mediated by stimulation of the adrenal medulla and through this by the release of sympathomimetic amines. These results, together with those already described by Page and McCubbin (1953), Schneider et al. (1954), and Thieblot et al. (1957) do not confirm experimentally the statements of Waldenström and Ljungberg (1955) who maintain that 5-HT stimulates the adrenals to secrete adrenalin, or at least they show that this secretion does not play an appreciable part in the production of the hæmodynamic changes induced by 5-HT. It can be observed, on the other hand, that adrenalectomy significantly reduces the hypertensive response of 
the pulmonary veins to 5-HT. In this respect, our earlier statements on the effect of hexamethonium on venous hypertension hold good.

Summing up, therefore, we may affirm that in the dog 5-HT acts on the pulmonary circulation neither by the neurogenic route through stimulation of the autonomic nervous system, nor by the humoral route through release of adrenomedullary hormones into the blood stream. It would seem then that this substance provokes pulmonary arteriolar vasoconstriction through direct action on the vessels. We thus agree with Rose (1957) and Rudolph and Paul (1957) who reached the same conclusions by different methods.

These experiments also produced some collateral results that seem to us worth mentioning. First, injection of hexamethonium in the intact animal was followed by a highly significant fall in pressure in the femoral artery and a significant fall in the pulmonary veins while the pulmonary arterial pressure and the pulmonary arteriovenous gradient were unchanged. These results are mentioned since, while the hypotensive action of ganglioplegics on the pulmonary circulation in cases of pulmonary hypertension has been demonstrated (Gilmore et al., 1952; Freis et al., 1953; Halmagyi et al., 1953; Davies et al., 1954; Storstein and Tveten, 1954; Sancetta, 1955; Wade et al., 1956; Balchum et al., 1957; Yu et al., 1958), the effect of such substances on pulmonary pressure in man and animals in normal conditions is still not clear. Fowler et al. (1950) and Fowler (1960) have not encountered pulmonary hypotension in these cases and thus agree with our results, whereas Green and Bunnell (1950) and Sancetta (1955) obtained it in man and Thaddeus et al. (1953) and Wakim (1955) found it in the dog. The fact that after ganglionic block pulmonary arterial hypotension does not occur in the normal dog but does occur in men with pulmonary hypertension can be explained not only by the difference in species (Paton and Zaimis, 1949) but also by the difference in the degree of basal neurogenic vasoconstriction which is known to influence the action of ganglioplegics (Acheson and Moe, 1946; Moe et al., 1949; Paton and Zaimis, 1952).

Our second observation concerns the influence, up to now almost completely unrecognized, of adrenalectomy alone on pulmonary hæmodynamics. Our results show a highly significant fall in pressure in the pulmonary artery, a significant one in the femoral artery, and no changes at all in pulmonary venous pressure and pulmonary arteriovenous gradient. These observations seem to be worth further study aimed at interpreting their mechanism and significance.

\section{SUMMARY}

We have studied the mechanism whereby 5-HT produces pulmonary vasoconstriction in the dog. Using 22 dogs under chloralose anæsthesia, we observed the changes produced by 5-HT in the pressure in the catheterized pulmonary artery and vein, in the pulmonary arteriovenous gradient, and in the femoral arterial pressures. We then compared these results with those following the same injection in the same animals subjected to hexamethonium ganglionic block (10 dogs) and bilateral adrenalectomy (12 dogs).

The results show that 5-HT has a hypertensive effect on the pulmonary artery and vein, raising the arteriovenous gradient, and on the femoral artery. Neither ganglionic block nor adrenalectomy modify this hypertensive effect on the pulmonary artery, the arteriovenous gradient, or the femoral artery, while they reduce its effect on the pulmonary veins. This leads us to conclude that the pulmonary vasoconstriction provoked by $5-\mathrm{HT}$ is due neither to neurogenic mechanisms (intervention of the autonomic nervous system), nor to humoral mechanisms (liberation of sympathomimetic amines of adrenomedullary origin), but to direct action on the pulmonary vessels.

Contrary to its action in men with pulmonary hypertension, in animals in basal conditions, hexamethonium does not modify the pulmonary arterial pressure and the arteriovenous gradient; it exerts a hypotensive effect only on the femoral artery and the pulmonary veins.

Adrenalectomy reduces the pressure in the femoral artery and in the pulmonary artery but does not modify the arteriovenous gradient or the pulmonary venous pressure. 


\section{REFERENCES}

Acheson, G. H., and Moe, G. K. (1946). J. Pharmacol. exp. Ther., 87, 220.

Attinger, E. O. (1957). Amer. Heart J., 54, 837. (1959). J. Pharm. Belg., 14, 22.

Balchum, O. J., Gensini, G., and Blount, S. G. (1957). J. Lab. clin. Med., 50, 186.

Borst, H. G., McGregor, M., Whittenberger, J. L., and Berglund, E. (1956). Circulat. Res., 4, 393.

- - Berglund, E., and McGregor, M. (1957). J. clin. Invest., 36, 669.

Bracco, M., and Curti, P. C. (1958). Recenti Progr. Med., 25, 425.

Carlier, J., Lejeune-Ledant, G., and Barac, G. (1958). C. R. Soc. Biol. (Paris), 152, 1034.

Davies, L. G., Goodwin, J. F., and Van Leuven, B. D. (1954). Brit. Heart J., 16, 440.

Fowler, N. O., Westcott, R. N., Havenstein, V. D., Scott, R. C., and McGuire, J. (1950). J. clin. Invest., $29,1387$. (1960). Amer. J. Med., 28, 927.

Freis, E. D., Rose, J. C., Partenope, E. A., Higgins, T. F., Kelley, R. T., Schnaper, H. W., and Johnson, R. L. (1953). J. clin. Invest., 32, 1285.

Gilbert, R. P., Kuida, H., Hinshaw, L. B., and Visscher, M. B. (1957). Clin. Res. Proc., 5, 225.

Hinshaw, L. B., Kuida, H., and Visscher, M. B. (1958). Amer. J. Physiol., 194, 165.

Gilmore, H. R., Kopelman, H., McMichael, J., and Milne, I. G. (1952). Lancet, 2, 898.

Ginzel, K. H., and Kottegoda, S. R. (1953). Quart. J. exp. Physiol., 38, 225.

Gomez-Ferrer Bayo F. (1958). Med. esp., 40, 125.

Green, D. G., and Bunnel, I. L. (1950). J. clin. Invest., 29, 818.

Halmagyi, D., Felkai, B., Ivanyi, J., Zsoter, T., Tenyi, M., and Szucs, Zs. (1953). Brit. Heart J., 15, 15.

Kabins, S. A., Molina, C., and Katz, L. N. (1959). Amer. J. Physiol., 197, 955.

MacCanon, D. M., and Horvath, S. M. (1954). Amer. J. Physiol., 179, 131.

Moe, G. K., Rennick, B. R., Capo, L. R., and Marshall, M. R. (1949). Amer. J. Physiol., $157,158$.

Nahas, G. G. (1958). J. Physiol., 50, 425. and MacDonald, I. (1959). Amer. J. Physiol., 196, 1045.

Page, I. H. (1952). J. Pharmacol. exp. Ther., 105, 58.

and McCubbin, J. W. (1953). Circulat. Res., 1, 354.

Paton, W. D. M., and Zaimis, E. J. (1949). Brit. J. Pharmacol., 4, 381.

- (1952). Pharmacol. Rev., 4, 219.

Rose, J. C. (1957). J. clin. Invest., 36, 924. and Lazaro, E. J. (1958). Circulat. Res., 6, 283.

Rudolph, A. M., and Paul, M. H. (1957). Amer. J. Physiol., 189, 263.

Sancetta, S. M. (1955). Amer. Heart J., 49, 501.

Schneider, J. G., Gaunt, R., and Earl, A. E. (1954). J. Pharmacol. exp. Ther., $110,45$.

- and Yonkman, F. F. (1954). J. Pharmacol. exp. Ther., 111, 84.

Shepherd, J. T., Donald, D. E., Linder, E., and Swan, J. C. (1959). Amer. J. Physiol., $197,963$.

Storstein, O., and Tveten, H. (1954). Scand. J. clin. Lab. Invest., 6, 169.

Thaddeus, A. P., May, L. G., Bennet, A., Kobayashi, M., and Gregory, R. (1953). Amer. J. Med., $14,760$.

Thieblot, L., Duchene-Marullaz, P., and Berthelay, J. (1957). C.R. Soc. Biol. (Paris), $151,34$.

Vitolo, E., Obbiassi, M., Battioni, G. G., e Villa, A. M. (1957). Atti 19 ${ }^{\circ}$ Congr. Soc. Ital. Cardiol., p. 133.

Wade, E. G., Mackinnon, J., and Vickers, C. F. H. (1956). Brit. Heart J., 18, 458.

Wakim, K. G. (1955). Amer. Heart J., 50, 435.

Waldenström, J., and Ljungberg, E. (1955). Acta med. scand., 152, 293.

Yu, P. N., Nye, R. E. jr., Lovejoy F. W. jr., Schreiner, B. F., and Yim, B. J. B. (1958). J. clin. Invest., $37,194$. 